\title{
Liturgie en Letterkunde - 'n 'Herfs'-liturgie vir Paasfees in die Suidelike Halfrond
}

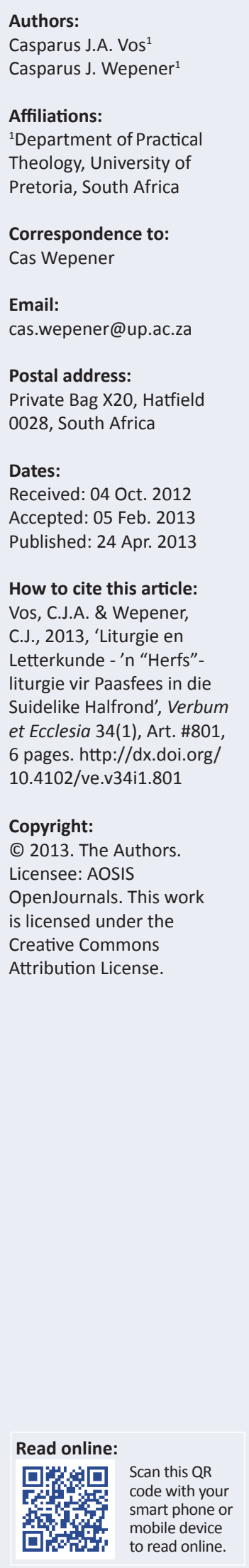

Liturgy and Literature - An Autumn liturgy for Easter in the Southern Hemisphere. The aim of this article was to explore possibilities regarding the liturgical inculturation of the Easter liturgy in the Southern Hemisphere. The Easter liturgy originated in the Northern Hemisphere, where it was and is celebrated during Spring with all its concomitant symbolism of new life. That symbolism seems to be lacking in the Easter liturgy in the Southern Hemisphere, where Easter occurs during Autumn. In order to address this issue an interdisciplinary exploration of the themes of both the Easter liturgy and the liturgical ordo was undertaken, as well as a study of Afrikaans poems about Autumn. An example of a liturgy making use of the ecumenicalprotestant fourfold order of worship [ordinarium] and enriched with liturgical elements based on the poems studied here as well as some traditions relating to the Easter liturgy [proprium] is presented. As a whole this article serves as an example of how Liturgical Studies can seek alliances with other disciplines in order to address its own questions and for its own purposes.

\section{Inleiding}

Die herfs kom altyd as 'n dreigement: die ligte karteling van die rand van 'n blaar, die koelheid van die lug en die vergang van die blomme. Die dae word korter en killer en die ure van hulle samesyn verminder. (Schoeman 1996:151)

So skryf Karel Schoeman in sy kortverhaal 'Die park na die val van die blare' oor 'n klein groepie Jode wat gereeld in 'n park bymekaarkom, maar telkens weer die kaddisj moet gaan bid nadat nog een van die klein groepie te sterwe gekom het. Uiteindelik bly Treisman alleen oor met niemand om die kaddisj, waarin God geprys en daar onder andere gevra word vir die koms van die Messias, vir hom te bid nie - die munisipaliteit sal hom moet begrawe. Op dieselfde Hoëveld wat Schoeman so trefseker in sy verhaal skets, word die koms van die Messias jaarliks gedurende daardie somber herfsseisoen liturgies deur Christene gevier. Terwyl die blare in die parke van Pretoria en Johannesburg val, die gras vergeel en die bytende winterluggie kerkruimtes binnekom, breek bloeisels liturgies deur en word God gedank vir die Messias wat gekom het.

In hierdie artikel tree die Afrikaanse Letterkunde (veral poësie) en die Liturgiewetenskap met mekaar in gesprek. Die eksplisiete bedoeling en oogmerk van hierdie interdissiplinêre praktiesteologiese (sien Walton 2012) verkenning is om aan te toon wat die kreatiewe moontlikhede is wanneer nie-teologiese dissiplines verken word om op 'n verantwoordelike wyse die bestaande liturgiese praxis te verryk. As sodanig verteenwoordig hierdie artikel ook 'n spesifieke benadering wat sommige liturge en eredienswerkgroepe van waarde mag vind en ook kan inspan met betrekking tot ander aanverwante velde en kunssoorte, soos byvoorbeeld Dramakunde en drama-tekste of Kunsgeskiedenis en skilderye of ander vorms van visuele kuns.

Die werkswyse wat gevolg word, behels in die eerste plek 'n kort verkenning van liturgiese diensordes en 'n posisionering van die ekumeniese diensorde soos wat dit ook neerslag gevind het in die nuutste Handleiding vir die erediens (reds. Clasen, Carstens, Bartlett, Schoeman et al. 2010) van die NG Kerk. Saam daarmee word die onderskeid tussen die sogenaamde vaste en verskuifbare handelinge [ordinarium en proprium] aangetoon en beredeneer, en dit sal dan as basis dien vir die 'eindproduk' wat in die artikel aangebied word. In 'n volgende deel word vier Afrikaanse gedigte ontleed. In die bespreking van die eerste drie gedigte tree die latere gedigte soms doelbewus met die oueres in gesprek. Die gedigte is 'Vroegherfs' (N.P. van Wyk Louw), 'Herfs' (D.J. Opperman) en 'Herfs' (Johann de Lange). In pas met die aard van die ekumeniese diensorde word 'n vierde gedig, 'Laaste dae van herfs', deur Cas Vos ook betrek; sodoende word die oopgelate kring van die ekumeniese liturgiese vierslag voltooi. In 'n derde fase van hierdie verkenning word die materiaal in gesprek gebring met bronmateriaal vir 'n spesifieke liturgie, te wete Paassondag 2013, wat in die Suidelike Halfrond gedurende die herfs gevier word. Tydens hierdie fase sal daar na die Skrif sowel as die tradisie van die liturgie van Paassondag gekyk word. Ten slotte word 'n volledige Paasliturgie aangebied wat uit die verf gekom het na aanleiding van hierdie liturgiese en literêre verkenning. 
In sy bekende artikel wat handel oor die gebruik van sosiale wetenskappe in liturgiewetenskap, 'For our own purposes: the appropriation of the social sciences in liturgical studies', doen die gereformeerde liturgis John Witvliet (2007) 'n kritiese evaluasie van hoe ander dissiplines in gesprek kan tree met die Liturgiewetenskap, maar pleit dan dat sulke alliansies 'for our own purposes' sal wees en dat die besondere objek en doel (vgl. Wepener 2006) van liturgiese navorsing nie in die slag sal bly nie. Hierdie artikel dien as 'n voorbeeld van hoe Letterkunde as vakgebied by uitstek 'n goeie gespreksgenoot vir Liturgiewetenskap kan wees, aangesien die twee velde heelwat in gemeen het, onder andere ' $n$ kreatiewe en kritiese wetenskaplike omgaan met die (W)woord.

\section{Die ekumeniese diensorde}

In navorsing wat handel oor die frekwensie van die viering van die Nagmaal in die Gereformeerde tradisie word daar dikwels na Zwingli se optrede in 1525 verwys (vgl. Wolterstorff 1992:294; McKee 2003:8, 12). Daarvolgens het Zwingli, ten einde lidmate se deelname aan die nagmaal van slegs een maal per jaar na vier maal te vermeerder, op Witte Donderdag 1525 vir die eerste keer in die geskiedenis van die liturgie die vaste kern van Woord en tafel in die Christelike liturgie geskei.

Skrif en tafel in kombinasie is deel van die kern van die Christelike liturgiese ordo soos dit deur die tradisie oorgelewer is en Schuman (1998a:39) verwys daarna as die oermodel. Ons sal na hierdie twee dele van die liturgie, die sogenaamde synaxis [Woorddiens] en eucharistie [Tafeldiens] verwys as die tweede en derde bewegings onderskeidelik. En alvorens daar uit die Woord gelees en gepreek kan word, moet 'n gemeente noodwendig eers versamel (die eerste beweging) en na afloop van die saamwees aan tafel word die versamelde gemeente ook weer die wêreld ingestuur (die vierde beweging) na die sogenaamde liturgie ná die liturgie (vgl. ook Van der Merwe 2009:173-178). In verskillende tradisies het hierdie verskillende bewegings verskillende name, soos die openings- en slotrite in die Oosters Ortodokse tradisie (Schuman 1998a:42).

Hierdie vier bewegings, wat ekumenies wyd aanvaar word en as die ekumenies-protestantse diensorde (Schuman 1998a:47) bekend staan, is ook die basiese ordo waarop die NG Kerk se nuutste eredienshandleiding (sien Clasen et al. 2010) se liturgiese voorstelle geskoei is. Dit is dus duidelik nie 'n nuwe ontwikkeling nie, maar eerder 'n teruggaan of herontdekking van iets wat eie is aan die skat van die tradisie van die Christelike liturgie.

In die liturgie is daar ' $n$ basiese onderskeid tussen die sogenaamde ordinarium en proprium. Eersgenoemde verwys na die vaste dele van die liturgie en laasgenoemde na die eietydse elemente wat 'n vaste deel van die liturgie vorm maar wat na gelang van die bepaalde tekste van 'n spesifieke Sondag ook kan verskil (vgl. Immink 2011:27-28). Vir die doeleindes van hierdie artikel sal na die ordinarium verwys word as die vaste vier bewegings van die ekumeniesprotestantse diensorde en die proprium as die verskuifbare handelinge wat in verskillende liturgieë op verskillende wyses aan bod kan kom. ${ }^{1}$

Met hierdie onderskeid tussen ordinarium en proprium binne die ekumenies-protestantse diensorde soos dit in moderne Liturgiewetenskap gebruik word in gedagte, word die Letterkunde vervolgens betrek in die vorm van enkele Afrikaanse herfs-gedigte. Daarna word die Paasliturgie onder die loep geneem.

\section{Vier herfs-gedigte}

Hier word nou telkens 'n gekose gedig weergegee en daarna word 'n literêr-kritiese bespreking van die bepaalde gedig gedoen. Die gedigte word hier chronologies volgens publikasiedatum aangebied, dus in die volgorde Louw, Opperman, De Lange en Vos. Die bedoeling van hierdie afdeling is om die gedigte se bruikbaarheid binne die liturgie en ook spesifiek gegewe die ekumeniese diensorde te berde te bring. Die bevindinge word in die slot in die vorm van 'n voorstel geïntegreer:
Vroegherfs
Die jaar word ryp in goue akkerblare, in wingerd wat verbruin, en witter lug wat daglank van die nuwe wind en klare son deurspoel word; elke blom word vrug, tot selfs die traagstes; en die eerste blare val so stilweg in die rook-vaal bos en laan dat die takke van die lang populiere al teen elke ligte môre witter staan.
O Heer, laat hierdie dae heilig word:
laat alles val wat pronk en sieraad was of enkel jeug, en vér was van die pyn; laat ryp word, Heer, laat $\mathrm{U}$ wind waai, laat stort my waan, tot al die hoogheid eindelik vas en nakend uit my teerder jeug verskyn. (Van Wyk Louw 1988)

\section{Grondstowwe by die Siklus van Seisoene \\ Herfs}
Die Pieke wissel in 'n kwepergloed wat appels en die laaste druiwe voed; die wingerde verroes tot rooi pontak terwyl uit eikebome koperblare sak.
Die bye en jangroentjies steek suikerkanne en kerse van die populiere brand. Ontspanne drink jy vonkelwyn en koer: op die dak
lê reeds die rye boerpampoene weggepak.
Nou met brokkolie, blomkool en sampioene spriet 'n dieper drif en soet uit suurlemoene; jy smul aan borriepatats en, gesmoor of gerook, voel jy in jou die eerste snoek wat loop. (Opperman 1979)

\section{Herfs}
Onder 'n helder koeler lug raak die vrugte swaar aan tak en loot. Die somermusikante tuimel uit die notebalk van telefoondrade

1.Vergelyk in hierdie verband ook die Preekstudies met liturgiese voorstelle (Orsmond 2011) asook Word and worship (Burger et al. 2011) - wat onderskeidelik deur 2011) asook Word and worship (Burger et al. 2011) - wat onderskeidelik deur
Communitas en Ekklesia uitgegee word - wat ook met die basiese onderskeid van vaste en verskuifbare handelinge werk en wat al redelik inslag gevind het in die liturgieë van gemeentes. 
en flikker noord. Die son sak

na warmer streke saans,

en die laaste dae swerm ylings

soos bye in die milde halflig.

Kontoere wat na skadu's ryp

en sap wat óp in dun skeute stoot

en spring, 'n dieper stem

wat uitroep in die appelboord:

Ja, ook hierdie kort verblyf

skink op sy tyd 'n speelse heuning. (De Lange 1984)

\section{Dae vol Herfs}

Al matvoet die dae vol herfs,

raak die blare se are verkalk

en dwarrel op die kaal grond,

al fluister wind in bome se ore

en begin takke sug oor verlies

waar 'n bries vlugtig daaraan raak,

al is duiwe besig om hees te koer

wanneer stilkoue veerbaadjies streel,

al loop die son rooivoet oor rante,

gloei my liefde vir jou

steeds sag en ryp. (Vos 2012)

N.P. van Wyk Louw se gedig 'Vroegherfs' vorm deel van sy 'Vier gebede by jaargetye in die Boland'. Die siklus is in Mei 1937 - Julie 1937 geskryf. Die gedigte is al vier sonnette.

'Vroegherfs' bestaan as vorm uit 'n oktaaf met die Shakespeariaanse sonnet as grondslag (a-b-a-b-c-d-c-d). Die sekstet is op die Petrarchiaanse sonnet geskoei (e-f-ge-f-g) (vir die sonnet as digvorm vgl. Hirsch 1999:309-312; Fenton 2003:62, 73, 77-81, 91-92; Beukes 2012:177-179). In die Afrikaanse literêre tradisie is die reeks soos die seisoene wat elke jaar herhaal word. Elke seisoen bly uniek en aangrypend.

Die ouer taalregister blyk uit woorde soos 'klare' (versreël 3) en 'teerder' (versreël 14). Ou woorde is egter skatte wat nie verlore mag gaan nie. Deur dié woorde word die taaltradisie bewaar.

Van Wyk Louw stel die verandering in die natuur in die eerste agt reëls voor (Esterhuizen 2012:158-162), van die rypwording van die 'goue akkerblare' tot 'die eerste blare val'. Daar is ook sprake van die 'witter lug wat daglank van die nuwe wind en klare son deurspoel word ...' Die ryping word voltrek deurdat 'elke blom' vrug word en 'die takke van die lang populiere al teen elke ligte môre witter staan.'

Die laaste ses reëls is ' $n$ aangrypende gebed (vgl. Esterhuizen 2012:159-160). Dit wat in die herfs gebeur, word nou in die mens voltrek. Die eerste van die laaste ses reëls begin met 'n gebed: 'O Heer, laat hierdie dae heilig word'. En dan word die betekenis daarvan onthul. Soos 'die eerste blare val' en 'die takke van die lang populiere al teen elke ligte môre witter staan', só noodsaaklik is die mens se verlies aan eiewaan en hoogmoed. Die 'hoogheid' wat oorbly, kom ná die gestrooptheid. Dit alles kom deur die Here se werking. Hy laat hierdie dae heilig word; Hy laat alles val wat pronk en sieraad was; Hy laat sy wind waai. Dan staan die mens nakend en jeugdig voor Hom.
D.J. Opperman se seisoengedigte noem hy 'Grondstowwe by die Siklus van Seisoene'. Dit het in 1979 verskyn en kom voor in sy bundel Komas uit 'n bamboesstok, wat geskryf is ná sy mirakelagtige terugkeer ná lewerversaking. Al vier die gedigte is twaalfreëlige gedigte wat deur koeplette gevorm is.

Die gedigte is Kaaps. Die Pieke is Kaaps. Al vier seisoengedigte begin met 'Die Pieke ...' Ook die vrugte, groente en vis waarna verwys word (appels, druiwe, borriepatats en snoek) is eie aan die Kaap. Alles gebeur 'ontspanne'. Hier word aan koningskos gesmul en aan vonkelwyn geteug. Dit is 'n maaltyd van oorvloed. Die snoek word deel van jou: jy voel 'in jou die eerste snoek wat loop.' Al is die gedig Kaaps, is dit nogtans tydloos. Dié maaltyd word seisoen na seisoen herhaal. Hier skemer reeds iets deur van die eucharistie, van dankbaarheid en viering.

Teenoor van Wyk Louw se 'akkerbome' staan Opperman se 'eikebome.' Opperman verwys net soos van Wyk Louw na 'populiere.'

Johann de Lange se gedig, 'Herfs', kom uit sy bundel Waterwoestyn (1984). Al is die gedig in terme van tyd ver van Van Wyk Louw verwyderd, kan die herfskwas van Louw in de Lange se gedig gemerk word. Louw se 'witter lug' word by de Lange "n helder koeler lug'. 'Die jaar word ryp ...' is by de Lange 'Kontoere wat na skadu's ryp ...' Daar is ook duidelike teenstellings: 'ligte môre' (Louw) en 'na skadu's ryp' (de Lange). De Lange se 'appelboord' het 'n raakpunt met Opperman se 'appels'.

De Lange se gedig het egter ' $n$ eie herfskleur. Dit is 'n rymlose sonnet wat iets van sy tyd aandui. Dit is veral die metafore wat 'n nuwe herfsseisoen inlui. 'Die somermusikante tuimel / uit die notebalk van telefoondrade / en flikker noord.' Wat veral in de Lange se gedig opval, is die verwysing na klank: 'Die somermusikante...', '...die laaste dae swerm ylings / soos bye in die milde halflig', '...'n dieper stem / wat uitroep in die appelboord'. Daar is by de Lange ook sprake van oorvloed en soetigheid. $\mathrm{Al}$ is die herfsseisoen kort, skink dit "n speelse heuning'. Die bye is 'n aanloop tot die heuning. Die wyse waarop hierdie gedig aan die Woorddiens diensbaar kan wees, sal later aan bod kom.

Cas Vos se gedig, 'Dae vol herfs', is 'n vrye vers (vgl. hieroor Odendaal 2012:182-187). Natuurbeelde, visuele vergestalting, klankspel ('bome' en 'ore', 'sug' en 'koer') en personifikasie word as poëtiese bindmiddele gebruik. Die kosmiese ('blare', 'grond', 'bome', 'takke', 'rante') kry 'n persoonlike kleur. Dit dui ook aan hoe innig mens en natuur verbind is. Daar is ook 'n verwysing na die tortels van die bome: 'duiwe wat hees koer / wanneer stilkoue veerbaadjies streel'.

'Dae vol herfs' is 'n liefdesgedig wat herfsbeelde gebruik om die liefde te verklaar. Hoewel die gedig 'n persoonlike stempel dra, is die liefde só algemeen menslik dat dit op alle liefdesverhoudinge toegepas kan word. 


\section{Die Paasliturgie}

Soos reeds opgemerk in die inleiding van hierdie artikel, val die herfsseisoen in die Suidelike Halfrond saam met die Paassiklus van die liturgiese jaar. In sy klassieke werk oor die liturgie van die eerste eeue merk Josef Jungmann (1959) op:

Easter is to the course of the year exactly what Sunday is to the course of the week: it is the great festival of salvation, the feast that was gradually extended into an entire cycle. (bl. 25)

Soos wat Sondag onder andere die dag van die opstanding is, is Paasfees en die Paassiklus die fees en seisoen van die opstanding (teologies gesproke hoort die kruis ook by die opstanding in Paastyd, net soos die leë graf by die kruis hoort in Lydenstyd) en is dit dus ' $n$ tyd wat ryk is aan die simboliek van nuwe lewe. Lente as seisoen in die natuur is dus 'n goeie kosmies-temporele konteks vir hierdie liturgiese tyd. Die outeurs van hierdie artikel is van mening dat hier ruimte vir en noodsaak is aan liturgiese inkulturasie van die Paassiklus om dit temporeel gesproke sinvol vir die Suidelike Halfrond aan te pas. 'n Voorbeeld van so 'n stuk liturgiese inkulturasie wat onses insiens reeds in die liturgie gedurende die Kerssiklus plaasgevind het, is die lied 'Welkom, o stille nag van vrede' waarin daar onder andere gesing word van "n helder somer-Kersfees onder die Suiderkruis'. Soortgelyke pogings tot liturgiese inkulturasie ten opsigte van die Paassiklus in die herfs is noodsaaklik en wel moontlik en hier kan die Letterkunde, soos reeds aangetoon, by uitstek van waarde wees.

Paasfees is die oudste liturgiese fees en die enigste wat tot en met die vierde eeu deur die hele kerk gevier is (Jungmann 1959:25). Die verband wat bestaan tussen Paasfees en Pasga verleen aan Paasfees ook 'n karakter van herinnering en van dankbaarheid (Vos \& Pieterse 1997:156-157). Baie bekend uit die eerste eeue is die groot dispuut oor die vasstelling van die Paasdatum. Daar was diegene wat van mening was dat omdat Christus op die 14de Nisan gesterf het, dít die datum van Paasfees moes wees (die sogenaamde Quattrodecimane), maar dan sou hierdie datum nie altyd op 'n Sondag geval het nie. Dit het die kerk in die Weste, waar die gebruik reeds ingeburger was om Paasfees op 'n Sondag te vier, omgekrap het. Die uiteindelike oplossing was om die Sondag direk ná 14 Nisan te gebruik (Monshouwer 1998:112-115; Jungmann 1959:26; White 2000:55) - daarom dat die Paasdatum jaarliks wissel, soos ons dit ook in Suid-Afrika ken. As sodanig kan Paassondag en die triduum van Paasfees (Goeie Vrydag, Stil Saterdag en Paassondag) gesien word as die episentrum van die liturgiese jaar, die kern en temporeel-simboliese hoogtepunte van die heilsgebeure (vgl. ook Van Leeuwen 2004:49-78). En van hierdie ou kern of episentrum het die liturgiese jaar ook na weerskante ontwikkel. Dit is onmoontlik om 'n groot tema in die liturgiese kalender soos Paasfees hier volledig te behandel en daarom word vervolgens slegs enkele van die belangrikste liturgiese gebruike soos dit voorgekom het in die geskiedenis van die liturgie uitgesonder. Hierdie gegewens kan saam met die voorafgaande inligting uit die Afrikaanse poësie en die liturgiese diensorde gebruik word om ' $n$ herfsliturgie vir Paasfees in die Suidelike Halfrond te ontwikkel.
As 'n Sondag en dag van die opstanding was Paasfees (Van Leeuwen 2004:69) deur die eeue nie 'n vasdag nie en die gebruiklike vasdae is ook opgehef in die daaropvolgende Paasseisoen (vgl. ook Jungmann 1959:27). Die liturgiesteologiese tekstuur van Paasfees was altyd dié van oorwinning, en dit is met oorgawe as sodanig gevier. Enige vrees vir triomfantelistiese neigings behoort besweer te word indien die viering binne die groter konteks van eerstens die triduum en tweedens die voorafgaande en daaropvolgende liturgiese seisoene van Lydenstyd en Paastyd beskou word (vgl. ook Vos \& Pieterse 1997:156). Paasdag as sodanig staan egter uit as ' $n$ dag van vreugde en die 50 dae daarna word deur Van Leeuwen (2004:69) as 'één lange zondag' beskryf.

Paassondag was in die eerste eeue 'n hoogtepunte binne die uitgebreide kategumenaatsproses (sien Wepener 2007a, 2007b). Die kandidate is op Paassondag gedoop, waarna hulle ' $n$ wit doopkleed omgehang is en vir die eerste maal toegang tot die nagmaal verkry het. 'n Besondere gebruik in die Paasoktaaf (oftewel ag dae ná Paassondag) binne die kategumenaatsproses was die sogenaamde mistagogiese kategese, wat onder andere behels het dat die pasgedooptes of neofiete eers geleer is wat die betekenis van die doop en nagmaal is. Die neofiete moes met ander woorde eers die sakramente beleef alvorens hulle die inhoudelike teologiese betekenis van die sakramente geleer is. Eerstens kom die gebruik van wit as kleur in Paastyd hier na vore en tweedens ook die klem op belewenis en ervaring as belangrike toevoeging tot die inhoudelike en kognitiewe. Hier sal natuurlik ook bygevoeg kan word die betekenis van die sakrament van die doop wat op Paassondag op 'n besondere wyse met tekste soos Romeine 6 resoneer - die gedoopte sterf met Christus om vir ewig met Hom te lewe.

Vos en Pieterse (1997:158) wys op die potensiaal van die simboliek van lig en duisternis in Paastyd en dat dit liturgies benut kan word. Wegman (1991) merk ook in hierdie verband op:

Het betekende dat men herdacht dat er harmonie was tussen licht en duisternis, gelijkwaardigheid tussen dag en nacht. Bovendien bracht men de schepping van het licht op de eerste dag in verband met de verrijzenis van Jezus, op de eerste dag van de week. (bl. 22)

Sodoende is die fees volgens Wegman (1991:22) beleef as 'n oomblik van ewewig en orde in die chaos waarin die mens en die kosmos saam deel. Ander praktyke wat anders was as gedurende die ander seisoene was die gebruik om tydens gebed te staan eerder as om te kniel soos die gebruik was, en daarmee simbolies uitdrukking te verleen aan die feit dat hulle met Christus opgestaan het (Jungmann 1959:27). Oor die algemeen is hier dus sprake van simbole wat 'n oorgang van dood na lewe en duisternis na lig uitdruk. Die uitdaging sal juis wees om hierdie simboliek liturgies sinvol tot uitdrukking te bring in 'n seisoen wat oënskynlik die teenoorgestelde simboliseer, naamlik herfs wat die naderende winter aankondig.

Opsommenderwys kan aangevoer word dat die belang van Paasfees as liturgiese tyd nie oorskat kan word nie, aangesien dit, net soos die week en die Sondag, geskoei is op die lewe van Christus. In essensie is Paasfees, net soos die res van 
die liturgiese jaar, 'n getuienis van Christus se oorwinning. White (2000) vat die betekenis hiervan as volg saam:

All is changed as Christ gives himself to us as the resurrected one at Easter. The Season of Easter begins with Easter Vigil and concludes on the Day of Pentecost. Ascension of the Lord commemorates the ending of Christ's historical visibility and the beginning of his sacramental visibility. (bl. 69)

En dit is waar ons dan nou ook ons verkenning van die tema verder voer, en dit ondersoek as 'n verryking van die bestaande Paasliturgie wat ' $n$ getuienis is van Christus se sakramentele sigbaarheid in ons eie dag.

\section{'n Herfsliturgie vir Paasfees in die Suidelike Halfrond}

Dit is opvallend hoe kleur die seisoen in al vier die herfsgedigte stempel. Kleur word as't ware 'n erkenningsen herkenningsteken. Kleur speel ook in die waarneming en ervaring van die visuele 'n sleutelrol.

'n Kleurvolle liturgie gee sin aan die ontmoeting tussen God en mens. Dit het ook liturgiese waarde vir die gemeente in hulle ervaring van die liturgie. Van Paasfees tot en met die Sondag ná Hemelvaart is die liturgiese kleur wit (Vos \& Pieterse 1997:167). Wit simboliseer oorwinning en fees word gevier. Die erediens kan in wit uitgedos word. Die nagmaaltafel, kansel en paadjies in die kerk kan wit skitter.

Vervolgens word enkele voorstelle aangebied vir die gebruik van die voorafgaande gedigte in die vier bewegings van die erediens en word verduidelik hoe die bestaande liturgie verryk kan word deur goed gekose woorde van hoë kwaliteit en terselfdertyd toeganklik vir 'n verskeidenheid erediensgangers.

\section{Enkele liturgiese momente}

\section{Toetrede}

Die ritueel van die intog of introïtus het in die Vroeë Middeleeue ontstaan. Die pontifikale hoogmis is in een van die katedrale in Rome gevier, en daar is 'n plegtige psalm aangehef op die oomblik wanneer die pous en sy gevolg hulle intog in die katedraal maak. Die optog na die kerk het mettertyd tot 'n volledige prosessie gegroei (Schuman 1998b:167; Vos 2001:455-456).

In die voorgestelde liturgie kan die gemeente die sekstet van Van Wyk se gedig hardop bid:

\footnotetext{
O Heer, laat hierdie dae heilig word:

laat alles val wat pronk en sieraad was of enkel jeug, en vér was van die pyn; laat ryp word, Heer, laat U wind waai, laat stort my waan, tot al die hoogheid eindelik vas en nakend uit my teerder jeug verskyn. (1988)
}

\section{Woorddiens}

In die Gereformeerde erediens staan die Woord sentraal. Veral die Reformasie onder die invloed van Luther en Calvyn het tot hierdie fokus gelei. Dit kan egter tot 'n eensydige liturgie lei as daar uit die oog verloor word dat die ander liturgiese momente ook kommunikasie van en met God bewerk (vgl. Vos \& Pieterse 1997; Oskamp \& Schuman 1998; SchmidtLauber 2003). In die voorgestelde liturgie kan die sekstet van Johan de Lange se gedig deur die liturg gelees word:

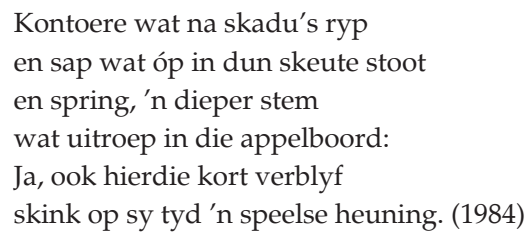

Die liturg kan enkele toeligtings oor die gedig gee. Die liturgiese betekenis van die gedig bestaan in die 'dieper stem / wat uitroep in die appelboord'. Die prediking is God se 'dieper stem' wat in die erediens uitgeroep word. Die preek is die skink van "n speelse heuning'. Die heuning-metafoor word in Psalm 19:11 gebruik om die soetheid en smaakvolheid van God se bepalings (Woord) te verduidelik. En in die eerste eeue na Christus het die neofiete, nadat hulle gedoop is en net voordat hulle vir die heel eerste keer deelgeneem het aan die Nagmaal, eers aan 'n lepel melk en 'n lepel heuning geproe. Dit was 'n simboliese herinnering dat, soos Augustinus dit gestel het, die liturgie (hier die Nagmaal) slegs die steierwerk is van die hemelse stad waarop gelowiges hoop. Só is die Woordverkondiging ook: Dit is heuning wat die hoorders nuwe moontlikhede laat proe, en hulle ook aan die beloofde land herinner, aan iets méér as slegs die land hier benede.

\section{Tafeldiens}

Op die Nagmaaltafel kan akkerblare, populierblare en druiwetrosse gerangskik word. Die Nagmaaltafel is oorlaai met God se genade en oorvloed (vgl. Boendermaker 1998:226-256; Vos \& Pieterse 1997:168-174; Schmidt-Lauber 2003:207-246). Die wyn verwys na Jesus Christus se bloed en die brood dui daarop dat Hy sy liggaam laat breek het om ons heel te maak en te voed.

Die liturg kan die eerste vier reëls van D.J. Opperman (1979) se gedig lees, en ook die woorde 'Ontspanne / drink jy vonkelwyn en koer'. Hy of sy kan wys op die oorvloed op die tafel. Daar is brood uit die grafoond en wyn uit die groot Bo-land. Hier kan ons op ons heil in Christus drink en word ons gevoed. Ons vier die fees van die ewige lewe.

\section{Uitsending}

Aanvanklik het die Rooms-Katolieke Kerk nie die seën geken nie. Die diens is slegs met die wegsendingsformule afgesluit: 'Ite, missa est' [Gaan, dit is die einde]. Vanaf die elfde eeu was die seën aan die einde van die mis 'n vry algemene gebruik (Barnard 1985:57). Die Reformatore gebruik die seën aan die einde van die diens in die Aäronitiese vorm van Numeri 6:24-26 (Vos \& Pieterse 1997:256). Ons vind dit in dié vorm ook by Calvyn, Pollanus en die 1574-Sinode van Dordrecht (Barnard 1985:577).

Die liturgie in die erediens loop uit op die erediens van die lewe. Wie oor die drumpel van die erediens die daaglikse lewe instap, leef onder die gemeenskap met God wat in die erediens plaasgevind het (Josuttis 1991:314; Van Leeuwen 1998:257-265). 
Vir die erediens van die lewe geld net een gebod: liefde vir God, bo alles en almal, en vir die naaste (vgl. Deut 6:4-9; Matt 22:34-40). Hiertoe seën die liturg die gemeente in die Naam van die Vader en die Seun en die Heilige Gees. Die liturg kan Numeri 6 of 2 Korintiërs 13:13 gebruik. Vervolgens kan hy of sy Cas Vos se gedig lees waarin die liefde konkreet gemaak word:

Al matvoet die dae vol herfs,
raak die blare se are verkalk
en dwarrel op die kaal grond,
al fluister wind in bome se ore
en begin takke sug oor verlies
waar ' $n$ bries vlugtig daaraan raak,
al is duiwe besig om hees te koer
wanneer stilkoue veerbaadjies streel,
al loop die son rooivoet oor rante,
gloei my liefde vir jou,
steeds sag en ryp. (2012)

\section{Ten slotte}

Liturgiese inkulturasie kan beskryf word as 'n voortgaande proses van krities-wederkerige interaksie tussen die liturgie en omringende kultuur of kulture sodat 'n heeltemal nuwe entiteit tot stand kom, te wete 'n geïnkultureerde liturgie (Wepener 2009:42). In hierdie proses van liturgiese inkulturasie daag die liturgie sekere aspekte van die kultuur uit op 'n kontra-kulturele wyse, maar aan die ander kant word ander aspekte van die kultuur weer bevestig of omhels. Dít was dan ook die doel van hierdie artikel, naamlik 'n eksemplariese oefening in liturgiese inkulturasie deur die Liturgiewetenskap in gesprek te bring met die Letterkunde en sodoende aan te toon, in die woorde van Van Wyk Louw '... dat alle rus die lewe dien'. Die Afrikaanse Letterkunde is dus, soos ander vakdissiplines ook sal wees, 'n waardevolle interdissiplinêre gespreksgenoot wat kon help om teologie wat temporeel-simbolies ingebed is in ' $n$ liturgie in die Noordelike Halfrond, ook oop te dek in dieselfde liturgie in die Suidelike Halfrond:

Op die ritme van liturgie en gedigte

beweeg ons volgens hemelse berigte

in die volheid van seisoen na seisoen

tot ons die nuwe hemel en aarde sien.

Kyk net, al die bome is immergroen

en ons kan Hom saam met engele dien. (Vos ongebundeld)

\section{Erkenning \\ Mededingende belange}

Die outeurs verklaar hiermee dat hulle geen finansiële of persoonlike verbintenis het met enige party wat hulle nadelig kon beinvloed in die skryf van hierdie artikel nie.

\section{Outeursbydrae}

C.W. (Universiteit van Pretoria) was verantwoordelik vir die konsep van die artikel waarna die outeurs se samewerking en mede-outeurskap op 'n gelyke bases was.

\section{Literatuurverwysings}

Barnard, A.C., 1985, Die erediens, NG Kerkboekhandel, Pretoria.

Beukes, M., 2012, 'Digvorme: Die digvorm as alkantbyl kap veelkantig,' in R. Scheepers \& L. Kleyn (reds.), ble. 171-182, Die Afrikaanse skryfgids, Penguin, Johannesburg.

Boendermaker, J., 1998, 'Maaltijd van de heer: Oecumenisch-protestant,' in P. Oskamp \& N.A. Schuman (reds.), De weg van de liturgie, pp. 236-244, Meinema, Zoetermeer

Burger, C.W., Theron, B., Griffiths, K. \& Harris, J. (eds.), 2011, Word and worship, Suggested sermon outlines and liturgies, Ekklesia, Stellenbosch.

Clasen, F., Carstens, C., Bartlett, A. \& Schoeman, F. (reds.), 2010, Handleiding vir die erediens, Bybelmedia, Wellington.

De Lange, J., 1984, Waterwoestyn, Human \& Rousseau, Kaapstad.

Esterhuizen, L., 2012, 'Algemene inleiding tot die skryf van poësie,' in R. Scheepers \& L. Kleyn (reds.), ble. 158-165, Die Afrikaanse skryfgids, Penguin, Johannesburg.

Fenton, J., 2003, An introduction to English poetry, Penguin Books, Londen.

Hirsch, E., 1999, How to read a poem, A Harverst Book Harcourt, San Diego.

Immink, G., 2011, Het heilige gebeurt. Praktijk, theologie en traditie van de protestantse kerkdienst, Uitgeverij Boekencentrum, Zoetermeer.

Immink, G., 1998, 'Heilig Avondmaal: Klassiek-greformeerd,' in P. Oskamp \& N.A Schuman (reds.), pp. 245-256, De weg van de liturgie, Meinema, Zoetermeer.

Josuttis, M., 1991, Der Weg in das Leben. Ein Einfürung in den Gottesdienst, Kaiser Verlag, München.

Jungmann, J.A., 1959, The early liturgy to the time of Gregory the Great, Darton, Longman \& Todd, Londen.

Louw, N.P. van Wyk., 1988, Versamelde gedigte, Human \& Rousseau/Tafelberg Uitgewers, Kaapstad.

McKee, E.A., 2003, 'Reformed worship in the sixteenth century,' in L. Vischer (red.) Christian worship in reformed churches past and present, pp. 3-31, William B. Eerdmans, Grand Rapids, MI.

Monshouwer, D., 1998, 'Pasen en de andere feesten,' in P. Oskamp \& N. Schuman (reds.), De weg van de liturgie, pp. 108-123, Meinema, Zoetermeer.

Odendaal, B., 2012, 'Vrye vers vs. tradisionele vorme: Die ontdekking van die wit,' in R. Scheepers \& L. Kleyn (reds.), ble. 182-187, Die Afrikaanse skryfgids, Penguin, Johannesburg.

Opperman, D.J., 1979, Komas uit 'n bamboesstok, Human \& Rousseau, Kaapstad.

Orsmond, E., 2011, Preekstudies met liturgiese voorstelle gebaseer op die leesrooster, Communitas/Bybelmedia, Wellington.

Oskamp, P. \& Schuman N.A. (reds.), 1998, De weg van de liturgie, Meinema, Zoetermeer.

Schmidt-Lauber, H-C., 2003, 'Die Eucharistie,' in H-C. Schmidt-Lauber, M. MeyerBlanck, Michael \& K-H. Bieritz (reds.), Handbuch der Liturgik, pp. 207-246, Vandenhoeck \& Ruprecht, Göttingen.

Schoeman, K., 1996, 'Die park na die val van die blare,' in A.H. De Vries (samesteller) Eeu. Honderd jaar van Afrikaanse kortverhale, 5 de hersiene uitg., ble. 151-153, Human \& Rousseau/Tafelberg, Kaapstad.

Schuman, N., 1998a, 'Een net van wegen,' in P. Oskamp \& N.A. Schuman (reds.), De weg van de liturgie, pp. 11-52, Meinema, Zoetermeer.

Schuman, N., 1998b, 'De Psalmen,' in P. Oskamp \& N.A. Schuman (reds.), De weg van de liturgie, pp. 165-174, Meinema, Zoetermeer.

Van der Merwe, I.J., 2009, 'Ontdek die beweging van die erediens,' in C. Wepener \& I.J. van der Merwe (reds.), Ontdekkings in die erediens, ble. 165-180, Lux Verbi. $\mathrm{BM}$, Wellington.

Van Leeuwen, M., 2004, Van feest naar feest. Over de christelijke feesten - hun geschiedenis en betekenis, Uitgeverij Balans, Nederland.

Van Leeuwen, M., 1998, 'Wegzending en zegen,' in P. Oskamp \& N.A. Schuman (reds.), De weg van de liturgie, pp. 257-265, Meinema, Zoetermeer.

Vos, C.J.A. \& Pieterse, H.J.C., 1997, Hoe lieflik is u woning, RGN Uitgewery, Pretoria.

Vos, C.J.A., 2001, 'Met 'n lied in die hart', Verbum et Ecclesia 22(2), 455-464. http:// dx.doi.org/10.4102/ve.v22i2.665

Vos, C., 2012, Weerloos lewe, Protea Boekhuis, Pretoria.

Walton, H., 2012, 'Poetics,' in B. Miller-McLemore (ed.), The Wiley-Blackwell Companion to Practical Theology, pp. 173-182, Wiley-Blackwell, Malden, MA.

Wegman, H.A.J., 1991, Riten en mythen. Liturgie in de geschiedenis van het chistendom, J.H. Kok, Kampen

Wepener, C.J., 2006, 'The object and aim of multi-disciplinary liturgical research,' Scriptura 93, 384-400.

Wepener, C.J., 2007a, 'Die lang pad van bekering. Deel 1. Die opkoms van die kategumenaat in die Patristieke tyd,' Nederduitse Gereformeerde Teologiese Tydskrif 48(1\&2), 307-317.

Wepener, C.J., 2007b, 'Die lang pad van bekering. Deel 2. Die verval van die kategumenaat in 'n staatskerk,' Nederduitse Gereformeerde Teologiese Tydskrif 48(1\&2), 318-329.

Wepener, C.J., 2009, 'From fast to feast. A ritual-liturgical exploration of reconciliation in South African cultural contexts', Liturgia Condenda 19, Peeters Pers, Leuven.

Wepener, C.J., 2010, Aan tafel met Jesus, Bybelmedia, Wellington.

White, J.F., 2000, Introduction to Christian worship, 3rd rev. edn., Abingdon Press, Nashville, TN.

Witvliet, J.D., 2007, 'For our own purposes: The appropriation of the social sciences in liturgical studies,' in P. Bradshaw \& J. Melloh (eds.), Foundations in ritual studies: A reader for students of Christian worship, pp. 17-40, SPCK, Londen.

Wolterstorff, N., 1992, 'The Reformed Liturgy,' D.K. McKim (ed.), Major themes in the Reformed tradition, W.B. Eerdmans, Grand Rapids. 